\title{
Determination of Copper in Wine by Anodic Stripping Voltammetry with Rotating Glassy Carbon and Microfiber Carbon Electrode
}

\author{
Desanka Ž. Sužnjević,,$^{1, *}$ Ferenc T. Pastor, ${ }^{2}$ Stanislava Ž. Gorjanović ${ }^{1}$
}

\author{
1 Institute of General and Physical Chemistry, P.O. Box 45, 11158 Belgrade 118, Serbia \\ 2 Faculty of Chemistry, University of Belgrade, Studentski trg 12-16, 11001 Belgrade, Serbia \\ * Corresponding author's e-mail address: desanka.suznjevic@gmail.com \\ RECEIVED: May 31, 2017 * REVISED: September 15, 2017 * ACCEPTED: September 15, 2017
}

THIS PAPER IS DEDICATED TO PROF. MIRJANA METIKOŠ-HUKOVIĆ ON THE OCCASION OF HER BIRTHDAY

\begin{abstract}
Anodic stripping voltammetry (ASV) with rotating glassy carbon electrode (RGCE) and microfiber carbon electrode ( $\mu$ FCE), both filmed with mercury, were used to determine copper content in wine. Influence of phenolics on in situ mercury film formation was studied. Wine and quercetin were added gradually into solution of $\mathrm{Hg}(\mathrm{II})$ in acetic acid-sodium acetate buffer ( $\mathrm{pH}=4.60)$. Reduction of $\mathrm{Hg}(\mathrm{II})$ was observed in both cases. In situ filmed electrode was found unsuitable. Results obtained using ex situ filmed RGCE and $\mu F C E$ were found in good agreement with ASV using hanging mercury drop electrode. Thus, ASV with ex situ mercury filmed electrodes can be recommended for accurate quantification of copper in complex samples containing phenolics, without any special pretreatments.
\end{abstract}

Keywords: anodic stripping voltammetry, glassy carbon electrode, carbon microfiber electrode, mercury film electrode, wine, copper.

\section{INTRODUCTION}

W IDE variety of phenolics is present in natural products, including grape and wine. They act as antioxidants through scavenging of reactive oxygen species (ROS) or chelate the metal ions responsible for the generation of ROS. Until now, various electrochemical techniques have been applied to determine wine phenolics and antioxidant (AO) activity. Cyclic voltammetry with glassy carbon electrode (GCE) was often used. ${ }^{[1-3]}$ Wine AO capacity was measured also by potentiometric titration, ${ }^{[4]}$ differential pulse polarography (DPP) at GCE ${ }^{[5,6]}$ and direct current polarography (DCP) at dropping mercury electrode (DME). ${ }^{[7,8]}$ Two recently developed DCP assays based on $\mathrm{Hg}$ (II) reduction were applied on individual compounds and various natural products including wine. ${ }^{[7-9]}$ Investigation of polarographic behavior of various phenolics and their interaction with metal ions was conducted by DCP and DPP. In presence of phenolics both $\mathrm{Hg}(\mathrm{II})$ reduction and $\mathrm{Cu}(\mathrm{II})$ complexation were observed.[10] Interaction of phenolics present in complex samples, such as wine, with metal ions can influence their direct electrochemical determination, making sample preparation or pretreatment necessary.

The analysis of metal-ions content in natural products, including grape and wine, was subject of numerous electrochemical studies. ${ }^{[11-15]}$ The anodic stripping voltammetry (ASV) at various working electrodes, such as dental amalgam $^{[11]}$, thick-film modified ${ }^{[12]}$ and DME, ${ }^{[16]}$ was widely applied.

Presence of $\mathrm{Cu}(\mathrm{II})$ in wines, usually associated with copper-based vineyard spraying or the addition of $\mathrm{Cu}(\mathrm{II})$ sulfate to remove sulfidic-of odors, is of particular interest due to the spoilage occurrence. Medium exchange stripping potentiometry at mercury filmed GCE was efficiently used to determine labile copper in wine. ${ }^{[13]}$ Anodic stripping voltammetry at hanging mercury drop electrode (HMDE) was successfully applied to quantify heavy metals including copper in wines, either subjected to digestion or not. ${ }^{[14-16]}$ 
The purpose of the present study was to determine $\mathrm{Cu}(\mathrm{II})$ content in chosen red wine using mercury filmed rotating glassy carbon electrode (RGCE) and microfiber carbon electrode ( $\mu \mathrm{FCE})$, considered environmentally friendlier than HMDE. Either in situ or ex situ mercury plated carbon electrodes have been used in parallel. Finding that $\mathrm{Hg}$ (II) reduction occurs in presence of phenolics ${ }^{[7-9]}$ lead to assumption that presence of phenolics could prevent formation of mercury film in situ. The assumption has been checked by gradual addition of wine and quercetin into buffered $\mathrm{Hg}(\mathrm{II})$ solution. Procedure with externally formed electrodes has been recommended as suitable for accurate determination of copper in wine, without any pretreatment.

\section{MATERIALS AND METHODS}

\section{Samples and Chemicals}

The wine samples, red wine Traminac and white wine Alexandria, were produced by winery "Vršački vinogradi" (Serbia) (vintage 1995). Quercetin (anhydrous) was obtained from Sigma (USA). The supporting electrolyte was acetic acid-sodium acetate buffer $(\mathrm{pH}=4.60)$. Standard solution of $1.00 \times 10^{-2} \mathrm{~mol} \mathrm{~L}^{-1} \mathrm{Hg}(\mathrm{II})$ was prepared from $\mathrm{HgCl}_{2}$ (Merck, Germany). $\mathrm{Cu}(\mathrm{II})$ solution $\left(5.0 \times 10^{-3} \mathrm{~mol} \mathrm{~L}^{-1}\right)$ was prepared daily from the $0.100 \mathrm{~mol} \mathrm{~L}^{-1}$ stock solution obtained by $\mathrm{Cu}$ ( $99.999 \%$, RTB Bor, Serbia) dissolved in $\mathrm{HNO}_{3}$ and neutralized with $\mathrm{NaOH}$ (Merck, Germany). The ultra pure water was used for all solution preparation. All chemicals used were of analytical grade quality.

\section{Instrumentation and Electrodes}

Anodic stripping voltammograms were recorded using either Polarographic analyzer PO4 Praha přistroje (Prague, Czech Rep.) equipped with X-Y recorder (Hewlett Packard, model 70158) or PAR (Princeton Applied Research, USA) Polarographic analyzer 174A equipped with $\mathrm{X}-\mathrm{Y}$ recorder Omnigraphic 2000 (Huston USA). The three electrode electrolytic cell was used. As a working electrode either rotating glassy carbon electrode (RGCE) with surface area of $1 \mathrm{~mm}^{2}$ or microfiber carbon electrode ( $\mu \mathrm{FCE}$ ) prepared from carbon fiber having diameter of about $10 \mu \mathrm{m}$ (TUP Dubrovnik, former Yugoslavia) were used. Carbon fiber $10 \mathrm{~cm}$ in length is fixed between two plastic bands. A reference electrode was saturated calomel electrode (SCE) while counter electrode was Pt-wire. Rotating speed of RGCE was $1500 \mathrm{rpm}$. When $\mu F C E$ was used the solution was stirred by magnetic stirrer set at $600 \mathrm{rpm}$.

The working RGCE electrode surface was cleaned before each experiment combining several cleaning procedures from the literature. After polishing with alumina powder $(\varphi=0.3 \mu \mathrm{m})$ electrode was rinsed with distilled water, rotated for $3 \mathrm{~min}$ in hot $20 \%(v / v) \mathrm{H}_{2} \mathrm{SO}_{4}$, again rinsed with distilled water, and finally ultrasonicated for $5 \mathrm{~min}$.

The working $\mu F C E$ surface renewal was enabled by cutting approximately half of $\mathrm{mm}$ before each experiment.

\section{Experimental Procedure}

In order to film RGCE with mercury, $\mathrm{Hg}$ (II) standard solution was added in electrolytic cell containing $20 \mathrm{~mL}$ of acetic acid-sodium acetate buffer $(\mathrm{pH}=4.60)$.

The dependence of ASV current peak of mercury dissolution after deposition at RGCE: i) on $\mathrm{Hg}$ (II) concentration in buffered solution with constant $\mathrm{Cu}(\mathrm{II})$ concentration ( $\left.0.05 \mathrm{mmol} \mathrm{L}^{-1}\right)$, ii) on wine amount in buffered solution containing $0.15 \mathrm{mmol} \mathrm{L}^{-1}$ of $\mathrm{Hg}(\mathrm{II})$ and $0.05 \mathrm{mmol} \mathrm{L}^{-1} \mathrm{Cu}(\mathrm{II})$ and iii) on quercetin concentration in the presence of 0.10 $\mathrm{mmol} \mathrm{L}^{-1} \mathrm{Hg}(\mathrm{II})$ and $0.01 \mathrm{mmol} \mathrm{L}^{-1} \mathrm{Cu}(\mathrm{II})$ was followed. Electrolysis was performed at cathodic potential of $-1.0 \mathrm{~V}$ during $60 \mathrm{~s}$. The potential scan rate was $200 \mathrm{mVs}^{-1}$ and final anodic potential was from 0.5 to $1.0 \mathrm{~V}$ vs SCE.

Determination of $\mathrm{Cu}(\mathrm{II})$ concentration in red wine Traminac by ASV with working RGCE and $\mu$ FCE electrodes plated in situ with mercury was performed from $20 \mathrm{~mL}$ of buffered solution containing $0.10 \mathrm{mmol} \mathrm{L}^{-1} \mathrm{Hg}(\mathrm{II})$ and $2 \mathrm{~mL}$ of red wine. Electrolysis was performed at cathodic potential $-1.2 \mathrm{~V}$ vs SCE during $60 \mathrm{~s}$ (RGCE) or $240 \mathrm{~s}(\mu \mathrm{FCE})$. After rotation of RGCE as well as magnetic stirring in case of $\mu F C E$ and rest time of $5 \mathrm{~s}$ ASV curves were recorded to the final potential $0.7 \mathrm{~V}$, with potential scan rate $500 \mathrm{mVs}^{-1}$.

Working electrodes (RGCE and $\mu \mathrm{FCE}$ ) were mercury plated externally (ex situ) from $20 \mathrm{~mL}$ of buffered solution containing $0.10 \mathrm{mmol} \mathrm{L}^{-1} \mathrm{Hg}(\mathrm{II})$. After $60 \mathrm{~s}$ (RGCE) or $240 \mathrm{~s}$ $(\mu \mathrm{FCE})$ of electrolysis at $-1.2 \mathrm{~V}$ electrodes were removed from cell solution, washed with distilled water and immersed into buffered solution containing $2 \mathrm{~mL}$ of wine Traminac. The same conditions were used as when plating was performed in situ.

Determination of $\mathrm{Cu}(\mathrm{II})$ concentration in wine Traminac by ASV method with HMDE electrode, was performed in parallel in Oenological Station (Vršac, Serbia), using HMDE and Polarograph PO4 Praha pristroje (Czech Rep.).

All experiments were performed at the room temperature.

\section{RESULTS AND DISCUSSION}

\section{Influences of Phenolics on Mercury Film Formation at Carbon Electrodes}

The influence of wine phenolics on mercury film formation at RGCE has been investigated. The effect of wine Alexandria as well as individual phenolic compound quercetin presence in plating solution has been followed.

The dependence of ASV current peak of mercury dissolution on its concentration, after deposition at RGCE from buffered solution (acetate buffer, $\mathrm{pH}=4.60$ ), in the presence 


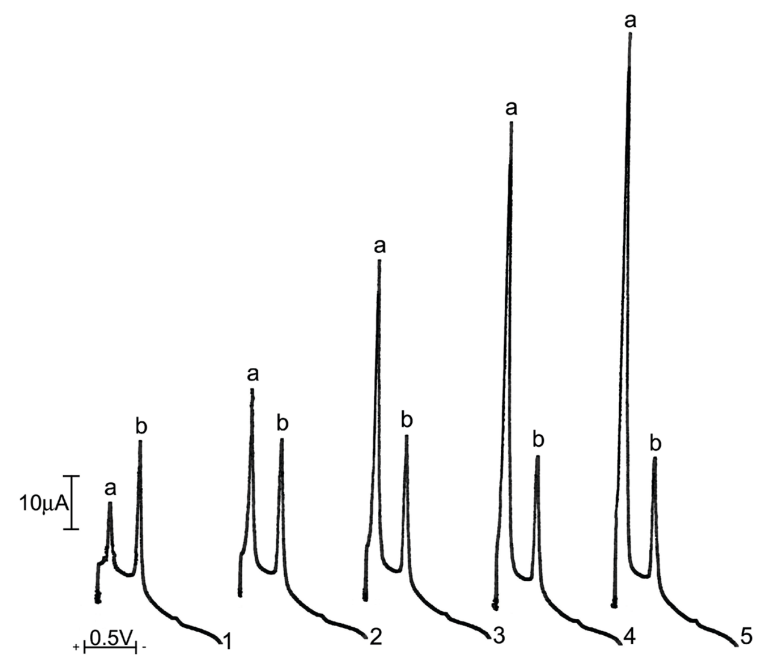

Figure 1. ASV curves of mercury (a) and copper (b) dissolution, deposited at RGCE from acetate buffer $(\mathrm{pH}=$ 4.6), upon gradual addition of $0.10 \mathrm{~mol} \mathrm{~L}^{-1} \mathrm{Hg}(\mathrm{II})$ standard solution in aliquots of $10 \mu \mathrm{L}$, in the presence of $0.05 \mathrm{mmol}$ $\mathrm{L}^{-1} \mathrm{Cu}(\mathrm{II})$.

of increasing $\mathrm{Hg}(\mathrm{II})$ and constant $\mathrm{Cu}(\mathrm{II})$ concentration (0.05 $\mathrm{mmol} \mathrm{L}^{-1}$ ), has been shown on Figure 1. Final anodic potential was $0.5 \mathrm{~V}$. As seen, dependence of current intensity of ASV mercury peak (Figure 1, peak a) on $\mathrm{Hg}(\mathrm{II})$ concentrations is linear while intensity of current peak attributed to copper (Figure 1, peak b) dissolution has been almost constant.

The behavior of mercury dissolution ASV current peak recorded on in situ filmed RGCE in presence of constant $\mathrm{Hg}$ (II) $\left(0.15 \mathrm{mmol} \mathrm{L}^{-1}\right)$ and $\mathrm{Cu}(\mathrm{II})\left(0.05 \mathrm{mmol} \mathrm{L}^{-1}\right)$ concentrations, upon gradually added wine, is shown on Figure 2. Final anodic potential was $0.7 \mathrm{~V}$. As seen, ASV peak of mercury dissolution (Figure 2, peak a) becomes significantly

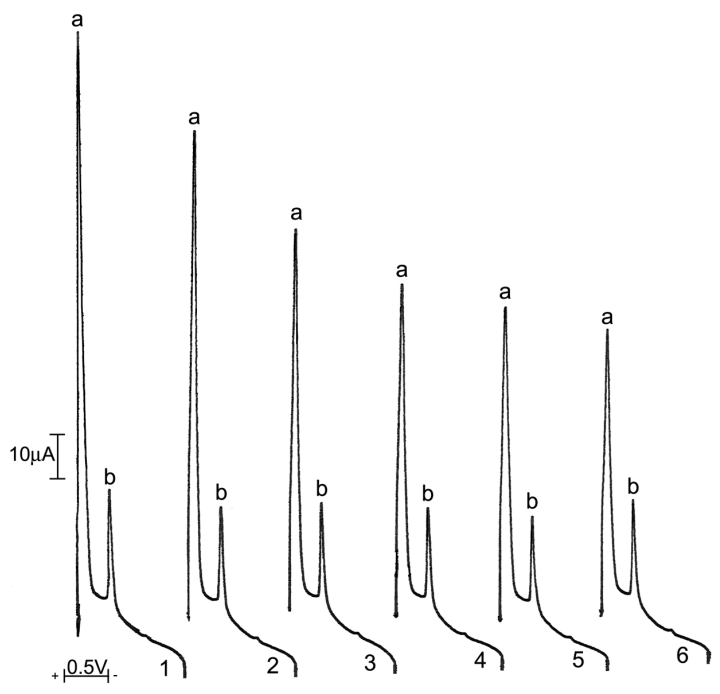

Figure 2. ASV curves of $0.15 \mathrm{mmol}^{-1} \mathrm{Hg}(\mathrm{II})$ and $0.05 \mathrm{mmol}$ $\mathrm{L}^{-1} \mathrm{Cu}(\mathrm{II})$ in acetate buffer $(\mathrm{pH}=4.6)$ before (1) and after addition of white wine Alexandria in aliquots of $100 \mu \mathrm{L}$ (2-6).

lower upon gradual addition of wine. Its decrease is linearly dependent on volume of wine added. Change of ASV current peak of amalgamated copper dissolution (Figure 2, peak $b$ ) in the presence of wine has been found negligible, probably due to low content of copper in white wines $(\approx$ $0.001 \mathrm{mg} \mathrm{L}^{-1}$ ).

The ASV peak of mercury dissolution (Figure 3, peak a) recorded on in situ filmed RGCE from buffered $0.1 \mathrm{mmol}$ $\mathrm{L}^{-1} \mathrm{Hg}(\mathrm{II})$ and $0.01 \mathrm{mmol} \mathrm{L}^{-1} \mathrm{Cu}(\mathrm{II})$ solution also linearly decreases with increase of amount of quercetin added, while copper dissolution peak (Figure 3, peak b) is almost constant. Final anodic potential was $1.0 \mathrm{~V}$.



Figure 3. ASV curves of $0.10 \mathrm{mmol} \mathrm{L}^{-1} \mathrm{Hg}(\mathrm{II})$ and $0.01 \mathrm{mmol} \mathrm{L}^{-1} \mathrm{Cu}(\mathrm{II})$ in acetate buffer $(\mathrm{pH}=4.6)$ before (1) and after addition of $0.2 \mathrm{mmol} \mathrm{L}^{-1}$ of quercetin in aliquots of $100 \mu \mathrm{L}(2-6)$. 




Figure 4. ASV curves obtained before (1) and after (2) addition of $2.0 \mathrm{~mL}$ of red wine Traminac, on in situ plated RGCE from $20 \mathrm{~mL}$ of acetate buffer $(\mathrm{pH}=4.6)$ in the presence of $0.1 \mathrm{mmol} \mathrm{L}^{-1}$ of $\mathrm{Hg}(\mathrm{II})$, and (3) after addition of $2 \mathrm{~mL}$ of Traminac on ex situ mercury plated electrode.

Similar behavior of ASV of mercury dissolution peak, noticed on Figures 2 and 3, indicate occurrence of $\mathrm{Hg}(\mathrm{II})$ reduction, both in presence of phenolics from wine and individual ones. Based on this finding, as well as on previous studies on $\mathrm{Hg}\left(\right.$ II) reduction, ${ }^{[7-9]}$ it can be supposed that accurate ASV determinations of copper as well as other heavy metal-ions amalgamated with mercury, is not possible using carbon electrodes plated with mercury in situ.

\section{Possibility of Copper Determination in Red Wine by ASV with in Situ and ex Situ Mercury Plated Carbon Electrodes}

In order to check effect of phenolic presence on mercury film formation and to develop method for accurate copper determination in wine, ASV with in situ and ex situ mercury film formation at RGCE and $\mu$ FCE has been applied in the analysis of red wine Traminac. ASV curves obtained have been compared.

When RGCE is filmed with mercury in situ from buffered $0.1 \mathrm{mmol} \mathrm{L}^{-1} \mathrm{Hg}$ (II) solution, a symmetric ASV peak of mercury dissolution at $0.4 \mathrm{~V}$ has been observed (Figure 4, curve 1, peak a). Upon addition of wine Traminac, significant decrease of peak a has been noticed (Figure 4, curve 2, peak a). Low intensity current (Figure 4 , curve 2, peak b), at about $-0.15 \mathrm{~V}$, has been attributed to copper dissolution. Additional current of low intensity (Figure 4, curve 2, peak c) that probably appears from the oxidation of some mercury organic compound becomes higher in the presence of higher amount of wine (not shown).



Figure 5. ASV curves obtained before (1) and after addition (2) of $2.0 \mathrm{~mL}$ of red wine Traminac, on in situ plated $\mu \mathrm{FCE}$ from $20 \mathrm{~mL}$ of acetate buffer $(\mathrm{pH}=4.6)$ in the presence 0.1 $\mathrm{mmol} \mathrm{L}^{-1}$ of $\mathrm{Hg}(\mathrm{II})$ and (3) after addition of $2 \mathrm{~mL}$ of Traminac on ex situ mercury plated microelectrode.

The intensity of mercury ASV dissolution peak obtained upon wine addition on ex situ formed mercury film at RGCE (Figure 4, curve 3, peak a) has been found the same as on in situ formed mercury film before the wine addition (Figure 4., curve 1, peak a). However, the copper dissolution current peak recorded upon red wine addition at ex situ formed mercury film (Figure 4, curve 3, peak b) has been found several folds higher than the same peak obtained at in situ formed mercury film (Figure 4., curve 2, peak b).

The same behavior of mercury and copper dissolution peaks obtained by ASV at RGCE has been noticed when $\mu$ FCE has been used (Figure 5, curves 1-3, peaks a and b).

Obviously, in presence of complex sample such as wine, formation of mercury film in situ is not regular due to reduction of $\mathrm{Hg}(\mathrm{II})$ with present phenolics, observed also previously. ${ }^{[7-9]}$ Results presented here confirm assumptions that ASV determination of $\mathrm{Cu}(\mathrm{II})$ in complex samples containing phenolics requires mercury film to be prepared ex situ.

\section{Determination of Copper in Red Wine by ASV with ex Situ Mercury Plated RGCE and $\mu \mathrm{FCE}$}

The concentration of $\mathrm{Cu}(\mathrm{II})$ in red wine Traminac has been determined by ASV with RGCE and $\mu F C E$. The calibration curve for each electrode has been constructed for $\mathrm{Cu}$ (II) concentration from 0.05 to $0.25 \mathrm{mg} \mathrm{L}^{-1}$. Value of $\mathrm{Cu}(\mathrm{II})$ determined from three successive ASV measurements on 
ex situ formed mercury film RGCE $\left(0.15 \pm 0.03 \mathrm{mg} \mathrm{L}^{-1}\right)$ and $\mu F C E\left(0.13 \pm 0.02 \mathrm{mg} \mathrm{L}^{-1}\right)$ has been found in good agreement. Also, obtained results corroborated well with the result obtained by ASV with HMDE electrode $(0.11 \pm 0.03$ $\left.\mathrm{mg} \mathrm{L}^{-1}\right)$.

\section{CONCLUSION}

Application of anodic stripping voltammetry (ASV) with working rotating glassy carbon electrode (RGCE) and microfiber carbon electrode ( $\mu \mathrm{FCE}$ ) mercury plated in situ has not been found useful in determination of $\mathrm{Cu}$ (II) present in complex samples containing phenolics, such as wine. Occurrence of $\mathrm{Hg}(\mathrm{II})$ reduction in presence of individual phenolics and complex samples containing them has been supposed to be responsible for irregular mercury film formation at electrodes plated in situ. It has been proved that phenolics from wine prevent regular formation of mercury deposit as well as amalgam of the investigated metal. Concentration of copper in wine Traminac has been successfully determined applying ASV with externally mercury filmed electrodes. Quantity of copper obtained by ASV with both RGCE and $\mu$ FCE, has been found in good agreement with result obtained by applying ASV with hanging mercury drop electrode (HMDE).

Acknowledgment. This paper is dedicated to dear friend and distinguished Professor Emeritus Mirjana Metikoš-Huković on the occasion of her solemn anniversary.

\section{REFERENCES}

[1] P. A. Kilmartin, H. Zou, A. L. Waterhouse, J. Agric. Food Chem. 2001, 49, 1957.
[2] P. A. Kilmartin, H. Zou, A. L. Waterhouse, Am. J. Enol. Vitic. 2002, 53, 294.

[3] J. Piljac, S. Martinez, T. Stipcević, Z. Petrović, M. Metikoš-Huković, Am. J. Enol. Vitic. 2004, 55, 417.

[4] S. Martinez, L. Valek, J. Piljac, M. Metikoš-Huković, Eur. Food Res. Technol. 2005, 220, 658.

[5] A. Javier Blasco, M. Cristina Gonzalez, A. Escarpa, Anal. Chim. Acta 2004, 511, 71.

[6] V. Sousa, C. da Rocha, C. Lucia Cardoso, D. Helena, S. Silva, M. Valnice, B. Zanoni, J. Food Anal. 2004, 17, 619.

[7] D. Ž. Sužnjević, F. T. Pastor, S. Ž. Gorjanović, Talanta 2011, 85, 1398.

[8] D. Ž. Sužnjević, Pastor, Gorjanović, Electrochim. Acta 2015, 168, 240.

[9] D. Ž. Sužnjević, M. Petrović, F. T. Pastor, M. Veljović, S. Zlatanović, M. Antić, S. Ž. Gorjanović, J. Electrochem. Soc. 2015, 162, H428.

[10] S. Milić, N. Potkonjak, S. Gorjanović, S. VeljovićJovanović, F. T. Pastor, D. Ž. Sužnjević, Electroanal. 2011, 22, 2935.

[11] O. Mikkelsen, K. Schroder, Anal. Chim. Acta 2002, 458, 249.

[12] Kh. Z. Brainina, N.Yu. Stozhko, G. M. Belysheva, O. V. Inzhevatova, L. I. Kolyadina, C. Cremisini, M. Galletti, Anal. Chim. Acta 2004, 514, 227.

[13] A. Clark, G. Scollary, Electroanal. 2006, 18, 1793.

[14] C. Wiese, G. Schwedt, Fresenius J. Anal. Chem. 1997, 358, 718.

[15] A. M. Baldo, S. Daniele, G. A. Mazzocchin, Electroanal. 1998, 10, 410.

[16] O. Mikkelsen, K. Schoder, Anal. Chim. Acta 2002, 458, 249. 